\title{
Changes in vasoactive pathways in congenital diaphragmatic hernia associated pulmonary hypertension explain unresponsiveness to pharmacotherapy
}

\author{
Daphne S. Mous ${ }^{1}$, Marjon J. Buscop-van Kempen ${ }^{1}$, Rene M. H. Wijnen ${ }^{1}$, Dick Tibboel ${ }^{1}$ and Robbert J. Rottier ${ }^{1,2^{*}}$
}

\begin{abstract}
Background: Patients with congenital diaphragmatic hernia $(\mathrm{CDH})$ have structural and functional different pulmonary vessels, leading to pulmonary hypertension. They often fail to respond to standard vasodilator therapy targeting the major vasoactive pathways, causing a high morbidity and mortality. We analyzed whether the expression of crucial members of these vasoactive pathways could explain the lack of responsiveness to therapy in CDH patients.

Methods: The expression of direct targets of current vasodilator therapy in the endothelin and prostacyclin pathway was analyzed in human lung specimens of control and CDH patients.

Results: $\mathrm{CDH}$ lungs showed increased expression of both ETA and ETB endothelin receptors and the rate-limiting Endothelin Converting Enzyme (ECE-1), and a decreased expression of the prostaglandin- $I_{2}$ receptor (PTGIR). These data were supported by increased expression of both endothelin receptors and ECE-1, endothelial nitric oxide synthase and PTGIR in the well-established nitrofen-CDH rodent model.

Conclusions: Together, these data demonstrate aberrant expression of targeted receptors in the endothelin and prostacyclin pathway in $\mathrm{CDH}$ already early during development. The analysis of this unique patient material may explain why a significant number of patients do not respond to vasodilator therapy. This knowledge could have important implications for the choice of drugs and the design of future clinical trials internationally.
\end{abstract}

Keywords: Nitric oxide, Endothelin, Prostacyclin, Development, Lung, Vasculature, Vasodilation

\section{Background}

Pulmonary hypertension $(\mathrm{PH})$ is the leading cause of morbidity and mortality in patients with congenital diaphragmatic hernia $(\mathrm{CDH})$ [1]. The altered development of the pulmonary vasculature and the disordered pulmonary vascular remodeling [2] in combination with the imbalance of vasoactive mediators caused by endothelial dysfunction result in the arrest of pulmonary vascular growth in these patients. Current treatment of $\mathrm{CDH}$ patients is not evidence based [3] and is derived from

\footnotetext{
*Correspondence: r.rottier@erasmusmc.nl
'Department of Pediatric Surgery, Erasmus Medical Center, Sophia Children's

* Correspondence: r.rottier@erasmusmc.nl
'Department of Pediatric Surgery, Erasmus Medical Center, Sophia Children's Hospital, Wytemaweg 80, 3015 CN, PO Box 2040, Rotterdam, The Netherlands

${ }^{2}$ Department of Cell Biology, Erasmus Medical Center, Rotterdam, The Netherlands
}

(c) The Author(s). 2017 Open Access This article is distributed under the terms of the Creative Commons Attribution 4.0 International License (http://creativecommons.org/licenses/by/4.0/), which permits unrestricted use, distribution, and reproduction in any medium, provided you give appropriate credit to the original author(s) and the source, provide a link to the Creative Commons license, and indicate if changes were made. The Creative Commons Public Domain Dedication waiver (http://creativecommons.org/publicdomain/zero/1.0/) applies to the data made available in this article, unless otherwise stated.

studies in adults, leading mainly to off-label and unlicensed use of drugs. Current knowledge is based on compassionate use and case reports, while some patients with $\mathrm{CDH}$ were included in trials that were underpowered for definitive conclusions. Even international therapy guidelines are based on consensus only (level 3 evidence) [4]. In 2012, experts evaluated the current antenatal and postnatal management of $\mathrm{CDH}$ and emphasized the importance of optimal management of $\mathrm{PH}$ in these patients [5]. Worldwide, PH treatment is mainly directed against the receptors of the endothelin (ET) and prostacyclin $\left(\mathrm{PGI}_{2}\right)$ pathways or the conversion of cyclic guanosine monophosphate (cGMP) in the nitric oxide (NO) pathway (Fig. 1a). In spite of these targeted treatments, it is still largely unknown how the different 


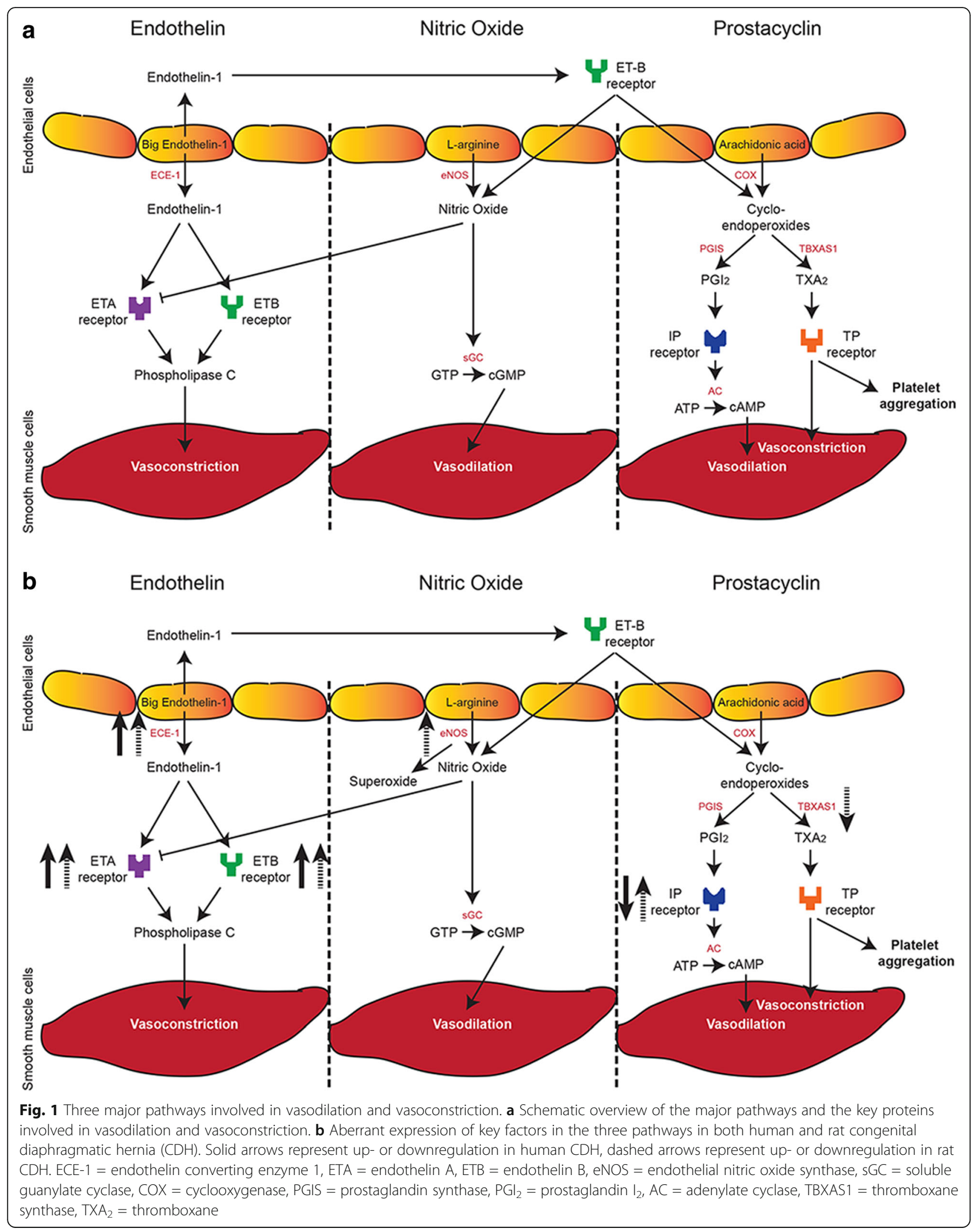


components of these pathways are expressed in lungs of unaffected individuals and $\mathrm{CDH}$ patients.

Previous studies reported increased levels of both the endothelin A (ETA) and B (ETB) receptors in human $\mathrm{CDH}$ as well as in the nitrofen rat model [6, 7]. Endothelin-1 (ET-1) is a potent vasoconstrictor [8] and is increased in lung tissue of patients with pulmonary hypertension. Moreover, high plasma levels of circulating ET-1 associated with the severity of $\mathrm{PH}$ in human $\mathrm{CDH}$ [9]. NO reduces the affinity of the ETA receptor for ET1 and may therefore terminate the ET-1 mediated signaling [10]. NO is synthesized by different NO synthases (NOS): endothelial NOS (eNOS), inducible NOS (iNOS) and neuronal NOS (nNOS), which are all expressed in the lung. However, only eNOS and, to some extent, iNOS, are expressed in the pulmonary vasculature and modulate pulmonary vascular tone $[11,12]$. Some human and rat $\mathrm{CDH}$ studies showed a decrease in eNOS $[13,14]$. However, we and others showed either no differences, or even an increased expression of eNOS in both human and rat $\mathrm{CDH}$ [15-19]. $\mathrm{PGI}_{2}$ is an important mediator of vasodilation, acting through the prostaglandin- $\mathrm{I}_{2}$ receptor (PTGIR) [20]. Several prostacyclin receptor agonists have been used in the treatment of persistent pulmonary hypertension of the newborn with variable effects [21-23]. Limited data are available about the use of these drugs in patients with $\mathrm{CDH}$, but the few available case reports show contrasting results [24-26]. An overview of the current data for human and the rat model is provided (Tables 1 and 2).

Since $\mathrm{CDH}$ patients respond poorly to current treatment strategies, we hypothesized that these effects might be due to an aberrant expression of important vasoactive factors. Here, we are the first to analyze the expression of the direct targets of the most commonly used vasodilator drugs, as well as some of the important members of the three major vasoactive pathways. Using unique

Table 1 Overview of studies in human CDH

\begin{tabular}{ll}
\hline Our group & Others \\
\hline $\begin{array}{l}\text { Increased expression of ETA } \\
\text { and ETB (protein level) }\end{array}$ & Increased ET-1 (plasma levels and protein \\
level) -[43] & - Increased ET-1 (plasma levels) [9] \\
Increased expression of & - Increased expression of ETA and ETB \\
ECE-1 (protein level) & (RNA and protein level) [6] \\
& - Increased expression of eNOS in arteriolar \\
No differences in eNOS & endothelium and alveolar epithelium \\
expression [16] & (protein level) [17] \\
& - No differences in eNOS expression \\
& (protein level) [19] \\
& - Decreased expression of eNOS (protein \\
& and RNA level) [14] \\
Decreased expression of & - No information about prostaglandin $\mathrm{I}_{2}$ \\
\hline Ptgir (protein level) & \\
\hline
\end{tabular}

Table 2 Overview of studies in experimental rat CDH

\begin{tabular}{ll}
\hline Our group & Others \\
\hline Increased expression of ETA & - Increased expression of ETA and \\
(RNA and protein level) and & ETB (RNA and protein level) [7] \\
ETB (RNA level) & \\
Increased expression of ECE-1 & - Increased expression of ET-1 after \\
(RNA level) & 1 and 6 h of ventilation (RNA \\
& level) [18] \\
& - Increased response of arterioles to \\
& ET-1 [44] \\
& - Increased expression of eNOS \\
Increased expression of eNOS & (RNA and protein level) [15] \\
(RNA and protein level) & - Increased expression of eNOS after \\
& 1 h of ventilation (RNA level) [18] \\
& - Decreased expression of eNOS \\
& (RNA and protein level) [13] \\
Increased expression of Ptgir (RNA & - Increased levels of prostaglandin I 2 \\
level) and decreased expression of & and an increased ratio of \\
Tbxas1 (RNA level) & prostaglandin I 2 and thromboxane \\
& (protein level) [34] \\
\hline &
\end{tabular}

patient lung material, we show an increased expression of both endothelin receptors and the rate-limiting endothelin converting enzyme (ECE-1), as well as a decreased expression of the prostaglandin $-\mathrm{I}_{2}$ receptor in human $\mathrm{CDH}$. Moreover, we found changes in the expression of these and other important factors of the pathways in rat CDH (Fig. 1b).

\section{Methods}

\section{Human lung samples}

Human lung samples were retrieved from the archives of the Department of Pathology of the Erasmus Medical Center, Rotterdam. In our high-volume, leading center of the EURO consortium [4], approximately 15 to 20 $\mathrm{CDH}$ patients a year are born, which ensures a large experience in the treatment of this disease. Paraffinembedded lung samples, lacking severe hemorrhage or necrosis, were selected of controls, of $\mathrm{CDH}$ patients and of patients with lung hypoplasia or pulmonary hypertension unrelated to $\mathrm{CDH}$. Only lung material of patients with a severe left-sided $\mathrm{CDH}$ and a survival of less than $7 \mathrm{~h}$ were selected to prevent secondary sequelae. Patient characteristics are described in Table 3.

\section{Animal model}

The well-established animal model was used, where in short pregnant Sprague-Dawley rats received either $100 \mathrm{mg}$ nitrofen dissolved in $1 \mathrm{ml}$ olive oil or just $1 \mathrm{ml}$ olive oil by gavage on gestational age day E9.5 [27]. Nitrofen induces left-sided CDH in approximately $70 \%$ of the offspring, while all pups have pulmonary hypertension. At day E21 pups were delivered by caesarean section and euthanized by lethal injection of pentobarbital. 
Table 3 Patient characteristics

\begin{tabular}{lllll}
\hline Disease & GA & Sex & Age of death & Cause of death \\
\hline Control & $18+0$ & Male & - & Abortion \\
& $24+6$ & Female & Minutes & Prematurity \\
& $26+5$ & Female & $1 \mathrm{~h}$ & Prematurity \\
& $33+0$ & Male & Minutes & Developmental delay \\
& $38+3$ & Male & Minutes & Asphyxia \\
& $38+5$ & Male & $1.5 \mathrm{~h}$ & Anencephaly \\
& $40+0$ & Female & $18 \mathrm{~h}$ & Asphyxia \\
$\mathrm{CDH}$ & $17+6$ & Male & - & Abortion \\
& $21+4$ & Male & - & Abortion \\
& $36+2$ & Male & Some hours & Respiratory failure \\
& $36+2$ & Female & Some hours & Respiratory failure \\
& $37+2$ & Male & $7 \mathrm{~h}$ & Respiratory failure \\
& $38+0$ & Male & $2 \mathrm{~h}$ & Respiratory failure \\
& $40+0$ & Female & Some hours & Respiratory failure \\
& $22+3$ & Male & - & Abortion \\
LH & $28+5$ & Female & 15 min & Respiratory failure \\
& $41+0$ & Male & 30 min & Respiratory failure \\
& $34+3$ & Female & 4 days & PPHN \\
& $37+1$ & Male & 4 days & Respiratory failure \\
\hline PH & & &
\end{tabular}

GA gestational age (weeks + days), $C D H$ congenital diaphragmatic hernia, $L H$ lung hypoplasia, $P H$ pulmonary hypertension, $P P H N$ persistent pulmonary hypertension of the newborn

\section{Immunohistochemistry staining}

Immunohistochemistry (IHC) was performed on $5 \mu \mathrm{m}$ thick paraffin sections of lungs of both rats and humans according to standard protocols, using the Envision $^{\mathrm{Tm}}$ detection system (Dako Cytomatic, Glostrup, Denmark) [28]. Briefly, sections were deparaffinized with xylene and rehydrated in gradual series of ethanol, after which antigen retrieval was performed by boiling samples in $10 \mathrm{mM}$ Tris (pH 9.0), 1 mM EDTA. Primary and Horse Redox Peroxidase conjugated secondary antibodies were diluted in antibody dilution buffer (DAKO) with 0,5\% Tween-20, and the peroxidase was detected with diamino-benzidine tetrahydrochloride (Fluka, Buchs, Switzerland). Validated primary antibodies used for IHC were Endothelin receptor A (ETA; 1:5000 (rat) 1:100 (human); Alamone, Jerusalem, Israel), Endothelin receptor B (ETB; 1:2500 (rat) 1:500 (human); Alamone), Endothelin Converting Enzyme (ECE-1; 1:500 (human); Abcam, Cambridge, MA, USA), endothelial nitric oxide synthase (eNOS; 1:400 (rat); Thermo Fisher Scientific, Waltham, MA, USA) and prostaglandin- $\mathrm{I}_{2}$ receptor (Ptgir; 1:1000 (rat) 1:500 (human); Cayman Chemical, Ann Arbor, Michigan, USA). Negative controls were performed by omitting the primary antibody.
Quantitative real-time polymerase chain reaction (qPCR) RNA isolation of whole lungs of rat pups, cDNA synthesis and subsequent qPCR analysis was performed as previously described [28]. The gene-specific primers used are listed in Table 4. Actb was used as reference gene.

\section{Statistical analyses}

Data are presented as means (SD) for normally distributed variables. Univariate analyses were performed using independent samples t-tests for normally distributed variables. The analyses were performed using SPSS 21.0 for Windows (Armonk, NY, USA: IBM Corp.). All statistical tests were two-sided and used a significance level of 0.05 .

\section{Results}

We analyzed the expression of receptors which are targeted during treatment, as well as other critical factors of the different vasoactive pathways, in order to unravel the unresponsiveness of $\mathrm{CDH}$ patients to current vasodilator therapies. Therefore, a unique set of lung material of $\mathrm{CDH}$ patients was used and the data were verified using the more dynamical nitrofen rat model.

\section{Human}

Besides the use of inhaled NO (iNO), current treatment is based on targeting the receptors in both the prostacyclin and endothelin pathway. Therefore, we analyzed the expression of the critical proteins of both pathways in human lung samples of control and $\mathrm{CDH}$ patients by immunohistochemistry. Human control lung samples showed little expression of the main target of the prostacyclin therapy, the important prostacyclin receptor PTGIR, in the fetal period. This sharply increased later during gestation at the preterm and term age. However this significant increase was absent in $\mathrm{CDH}$ (Fig. 2). The ETA receptor, which induces vasoconstriction and cell proliferation, was expressed in the small $(25-50 \mu \mathrm{m})$

Table 4 Primer sequences

\begin{tabular}{lll}
\hline Gene & Sequence (forward 5'- 3') & Sequence (reverse 5'- 3') \\
\hline Eta & AACCTGGCAACCATGAACTC & ATGAGGCTTTGGACTGGTG \\
Etb & CAGGATTCTGAAGCTCACCCTI & TCCAAAACCAGCAAAAAACTCA \\
Et-1 & TGTGCTCACCAAAAAGACAAGAA & GGTACTTTGGGCTCGGAGTTC \\
Ece-1 & GCAAGAACATAGCCAGCGAG & CTCCGAGTATCTTCATCCATCC \\
eNos & CATACTTGAGGATGTGGCTG & CCACGTTAATTTCCACTGCT \\
Sma & TGACCCAGATTATGTTGGAGAC & AGAGTCCAGCACAATACCAG \\
Ptgis & CATCAAACAGTTGTGGTCCT & CAAAGCCATATCTGCTAAGGT \\
Ptgir & CACGAGAGGATGAAGTTACCA & AATCCTCTGATCGTGAGAGGC \\
Tbxas1 & AGACTCAGGTTCCACTTCAG & TCACACCTGCCTTCTATGTC \\
Tbxa2r & ACTGTGAGGTGGAGATGATGG & CAGGATGAAGACCAGCAAGG \\
Actb & AGATGACCCAGATCATGTTGAG & GTACGACCAGAGGCATACAG \\
\hline
\end{tabular}




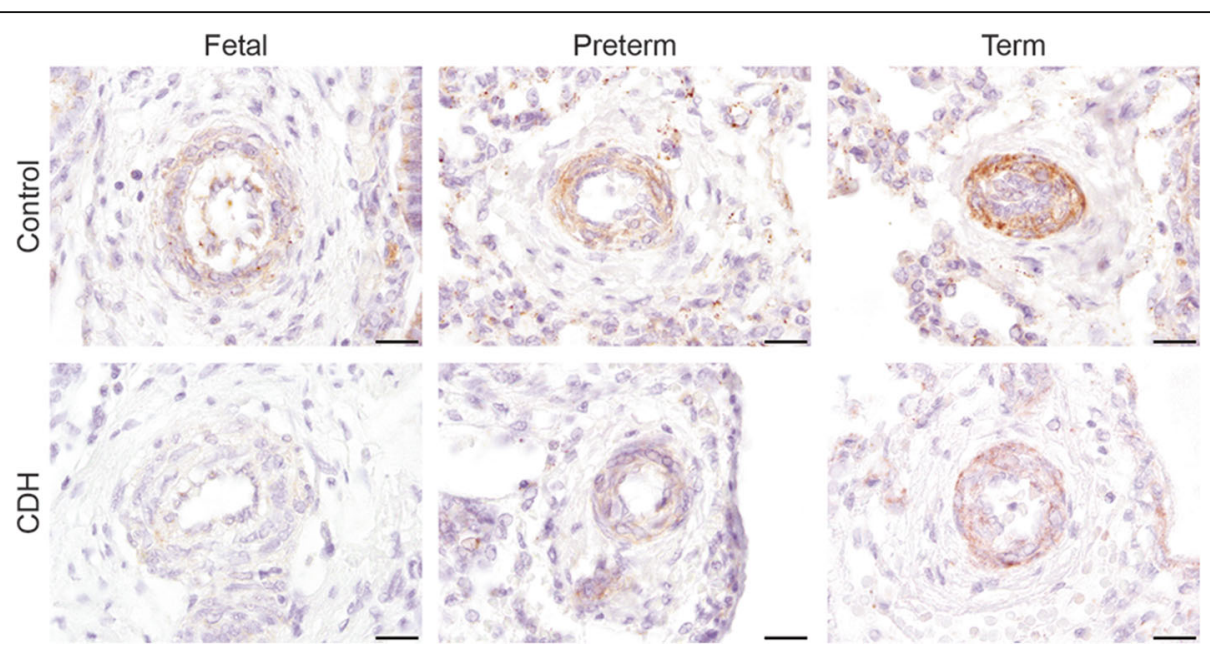

Fig. 2 Suppressed progression of prostaglandin- $I_{2}$ receptors during gestation in human $C D H$. Representative images show progressive expression of PTGIR in the vessels during gestation in human control lungs, which is reduced in lungs of human CDH patients. Scale bars represent $20 \mu \mathrm{m}$. Patients: GA $18+0,33+0$ and $38+0$ (control), GA $21+4,36+2$ and $37+2(\mathrm{CDH})$

and larger $(>50 \mu \mathrm{m})$ vessels as well as in the very small capillaries $(<25 \mu \mathrm{m})$ in $\mathrm{CDH}$. In contrast, the distribution of the ETA receptor in control lungs was limited to the small and larger vessels only (Arrowheads in Fig. 3a). The ETB receptor, involved in vasodilation through the release of $\mathrm{NO}$ and $\mathrm{PGI}_{2}$ (Fig. 1), was expressed both in the bronchial epithelium and in some of the larger vessels $(>50 \mu \mathrm{m})$ in $\mathrm{CDH}$ (Arrowheads in Fig. 3a). However, the expression of ETB in control lungs was found only in the bronchial epithelium (Fig. 3a). Next, we analyzed the expression of ECE-1, a membrane-bound metalloprotease that converts big-endothelin into the biologically active compound ET1 and it is a ratelimiting factor in the ET pathway. Early during gestation, in the fetal period, ECE-1 is minimally expressed in the vessels of the human control lung samples, with an increase at preterm and term age. Increased expression of this enzyme at both fetal, preterm and term age was observed in $\mathrm{CDH}$ (Fig. 3b), indicating a potential increased bio-availability of active ET-1 already at the fetal stage of development.

To exclude that the differences in expression patterns of the crucial prostacyclin - and endothelin receptors and the rate-limiting factor ECE-1 was solely an effect of lung hypoplasia ( $\mathrm{LH}$ ) or $\mathrm{PH}$, we performed immunohistochemistry on lungs of patients with $\mathrm{LH}$ and $\mathrm{PH}$ with other cause than $\mathrm{CDH}$. The PTGIR receptor expression was reduced in both $\mathrm{LH}$ and $\mathrm{PH}$ (Fig. 4a). Increased expression of ETA was detected in the smallest vessels in lungs of both $\mathrm{LH}$ and $\mathrm{PH}$ (Arrowheads in Fig. 4b), whereas increased expression of ETB was only observed in both small and very small vessels of lungs of $\mathrm{PH}$ patients (Arrowheads in Fig. 4c). ECE-1 was not expressed differently in both LH and PH lung samples (Fig. 4d).

\section{Rat}

In order to validate these interesting human data, we evaluated the expression patterns of the proteins of these three pathways in the nitrofen rat model. This was supplemented with RNA and protein expression analysis of related factors. Real-time qPCR showed that the mRNA expression of both the Eta and Etb receptors was significantly higher in lungs of E21 pups with $\mathrm{CDH}$ compared to those of control pups. We also analyzed the expression of the ETA and ETB ligand, Et-1, but no significant differences were found between the groups. However, the mRNA encoding the rate-limiting factor Ece-1 was significantly increased in $\mathrm{CDH}$ compared to control, confirming the human data (Fig. 5a). Next, we analyzed the protein expression pattern of the ET receptors with immunohistochemistry. The ETA receptor was expressed in the small capillaries of both groups at E15 until E21 with a stronger expression level in $\mathrm{CDH}$. At E21 only $\mathrm{CDH}$ lungs showed expression of the ETA receptor in the larger vessels $(>50 \mu \mathrm{m})$ (Fig. 5b). The ETB receptor was expressed in the bronchial epithelium of all lungs without significant differences between control and $\mathrm{CDH}$ at all ages (Fig. 5c). There was a significant higher mRNA expression of eNos in $\mathrm{CDH}$ rats compared to control in relation to all cells as well as in relation to only the smooth muscles cells (Fig. 6a) or endothelial cells (data not shown). This increased expression was clearly detectable with immunostaining in the larger and smaller $(<50 \mu \mathrm{m})$ vessels at E21. However, no obvious differences were noted earlier during development (E15 till E19) (Fig. 6b). Although there was no difference in expression of prostaglandin- $\mathrm{I}_{2}$ synthase (Ptgis) between control and CDH rat pups, there was a slight increase in the expression of Ptgir and the 

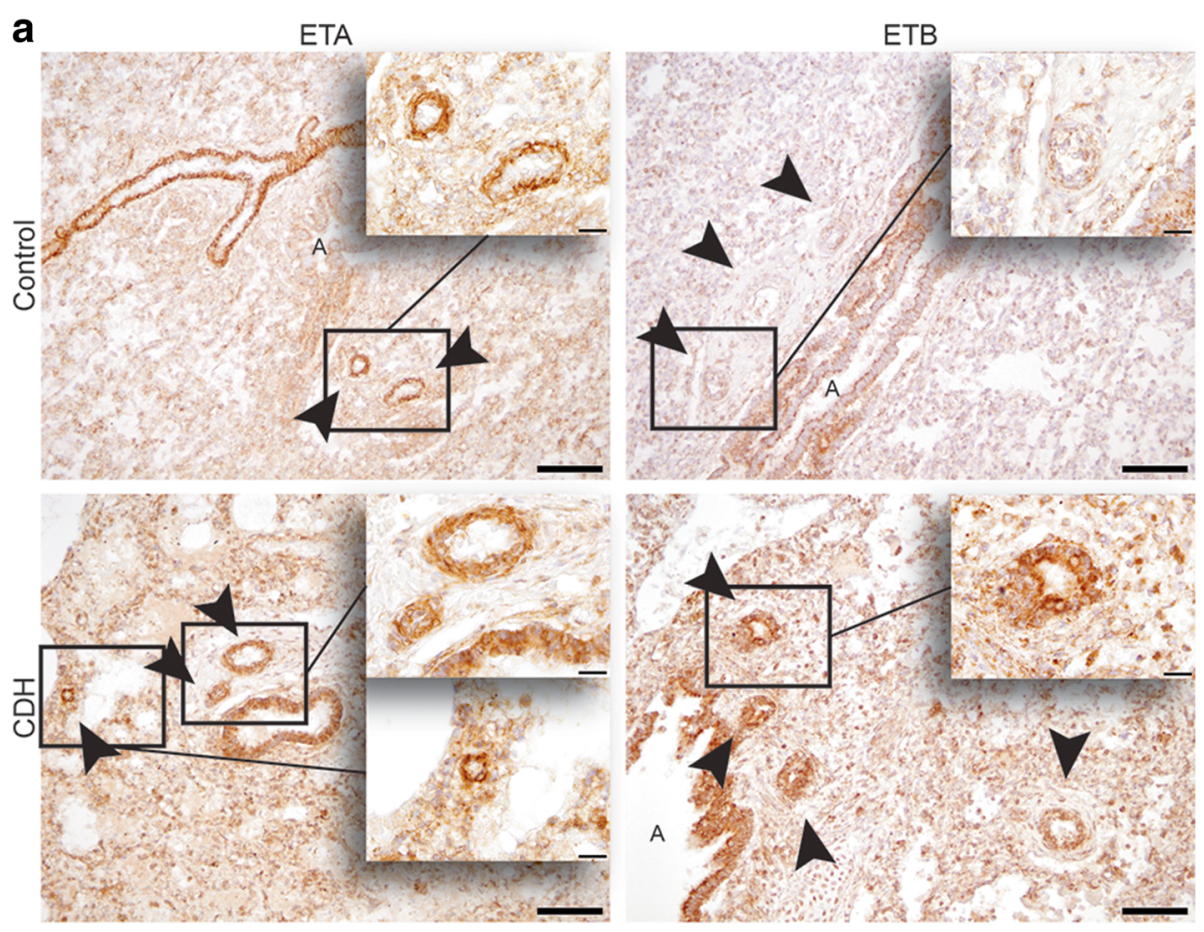

b

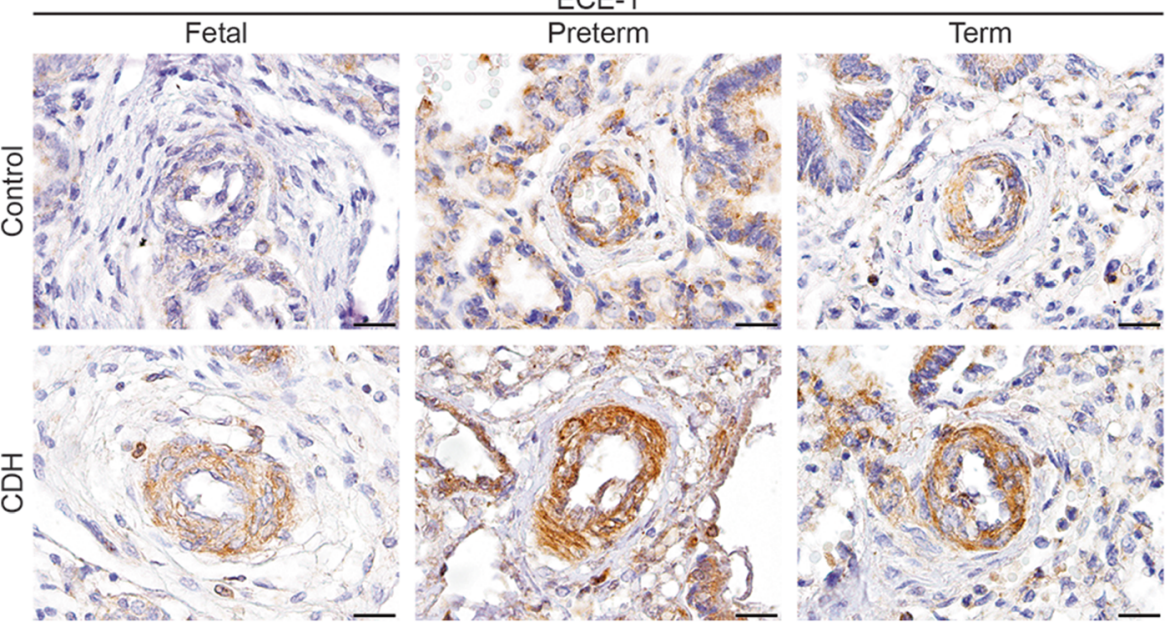

Fig. 3 Increased expression of ECE-1 and both ET receptors in human CDH. a Representative images show increased expression of ETA in the smaller vessels and clear expression of the ETB receptor in vessels in lungs of $\mathrm{CDH}$ patients compared to control. $\mathbf{b}$ ECE- 1 is increasingly expressed in the vessels in human control patients during gestation, whereas the expression is already high in the fetal stage of development in $\mathrm{CDH}$ patients. Arrows indicate vessels, A indicates airways. Scale bars represent $100 \mu \mathrm{m}$ (low power) and $20 \mu \mathrm{m}$ (high power). Patients: GA $38+3$ (control), GA $38+0$ and $37+2(\mathrm{CDH})(\mathrm{A}+\mathrm{B})$. Patients: $\mathrm{GA} 18+0,26+5$ and $38+0$ (control), GA $21+4,36+2$ and $37+2(\mathrm{CDH})(\mathrm{C}+\mathrm{D})$

prostaglandin- $\mathrm{E}_{1}$ receptor (Ptger 1$)$ in $\mathrm{CDH}$ at the mRNA level in both the whole lung as well as compared to the number of smooth muscle cells. In contrast, the expression of thromboxane synthase (Tbxas1), the enzyme converting prostaglandin $\mathrm{H} 2$ into thromboxane A2, which is in turn critical for vasoconstriction, was clearly reduced in $\mathrm{CDH}$, whereas the thromboxane receptor (Tbxa2r) did not show significant differences (Fig. 7a). However, immunostaining showed no clear differences in expression of PTGIR in the vessels between both groups (Arrowheads in Fig. 7b).

\section{Discussion}

This is the first combined study showing the aberrant expression of different important factors in the endothelin, $\mathrm{NO}$ and $\mathrm{PGI}_{2}$ pathways in $\mathrm{CDH}$ patients (Fig. 1b) and human patients with $\mathrm{LH}$ or $\mathrm{PH}$ unrelated to $\mathrm{CDH}$, possibly explaining why a large number of patients do 

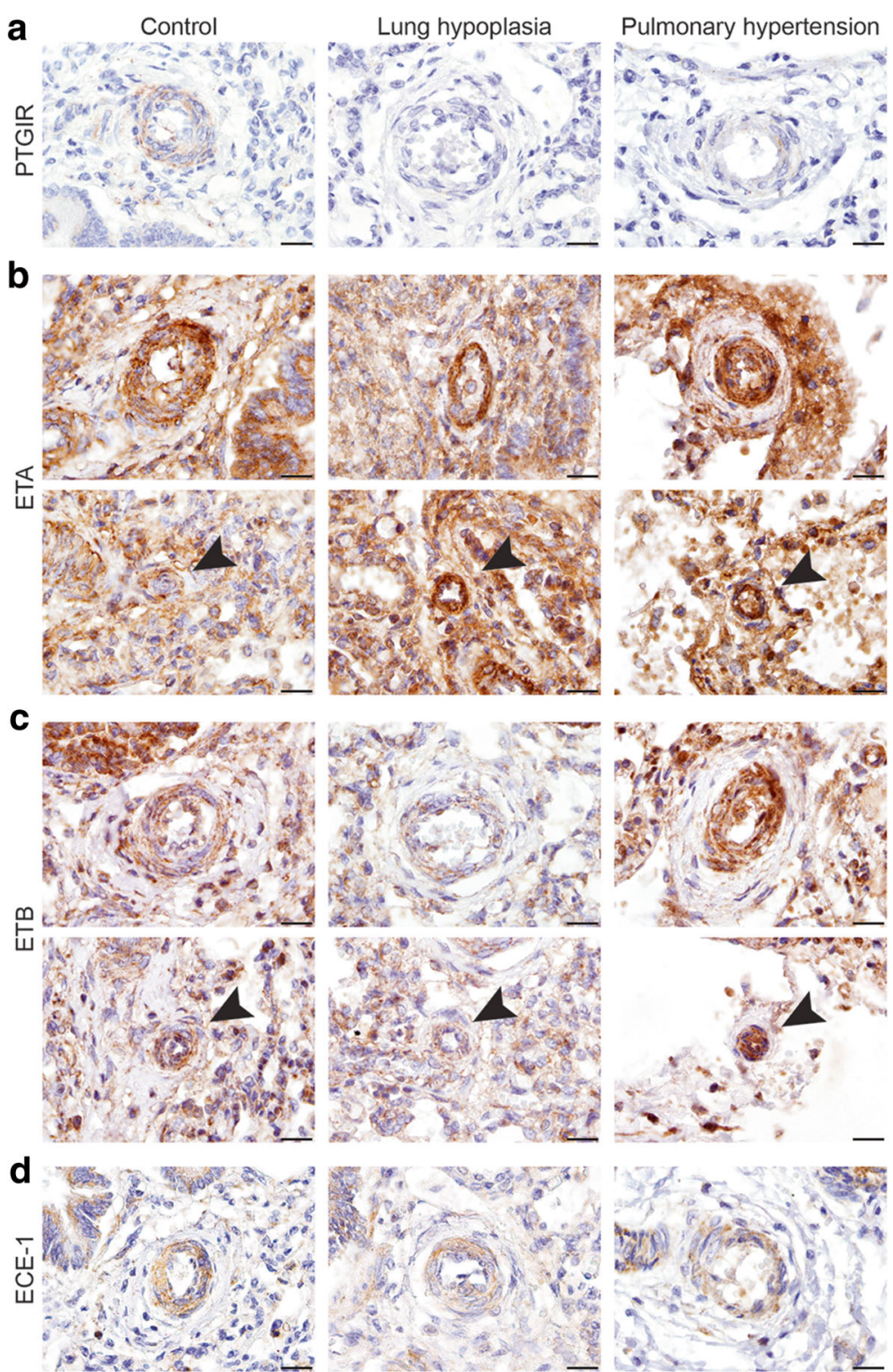

Fig. 4 Expression of prostaglandin and endothelin factors in human LH and PH patients. Representative images show expression of PTGIR (a), ETA (b), ETB (c) and ECE-1 (d) in patients with lung hypoplasia (LH) or pulmonary hypertension (PH) unrelated to CDH. The expression of ETA is increased in the smaller vessels of patients with $\mathrm{LH}$ and PH (b), and the expression of ETB is only increased in the vessels of patients with PH (c). ECE-1 is not differently expressed in the vessels both LH and PH lung samples (d)Scale bars represent 20 um. Arrows indicate very small vessels. Patients: GA $38+3$ (control), GA $41+0(\mathrm{LH}), \mathrm{GA} 34+3(\mathrm{PH})$

not respond to the current vasodilator therapy. We focused our research on direct targets of the most frequent used drugs to investigate the effectiveness of the current approach and combined this with the analysis of some key factors of the different pathways.

Since our unique human $\mathrm{CDH}$ material is scarce and a limiting factor, since only specimens of newborns who lived for a short period were analyzed to prevent secondary morphological changes, supplemental analyses were done on lung tissue of the nitrofen rat model.
In line with previous studies in both human and rat, we found a significant increased expression of the ETA and ETB receptor, important targets of vasodilator therapy, in human $\mathrm{CDH}$ patients and the rat model $[6$, $7,29]$. However, we are the first to show an increased expression of the crucial ECE-1 enzyme in both human pulmonary vessels of $\mathrm{CDH}$ patients and whole lung homogenates of nitrofen treated rat pups. ECE-1 converts big ET- 1 into the active form of ET- 1 and is the rate-limiting step in the production of ET-1 [30]. Although there was no apparent difference in total ET-1 


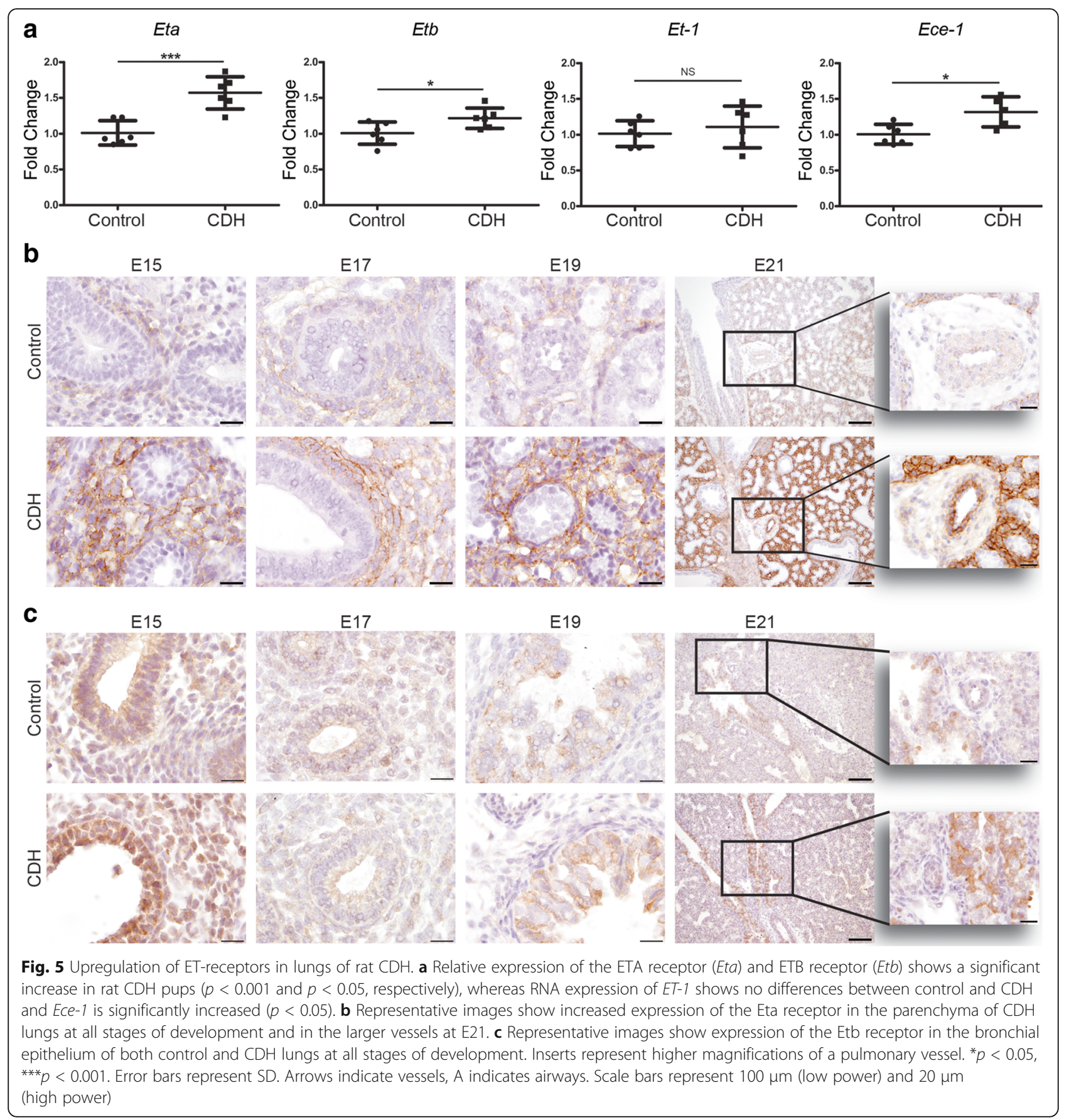

in $\mathrm{CDH}$ pups, the higher expression of ECE-1 in lungs of $\mathrm{CDH}$ pups may lead to an increase in the active form of ET-1.

Previously, we and others showed no apparent differences in the NO pathway $[16,19]$. In contrast to other studies $[13,14,19,29]$, we found an increased expression of eNOS in $\mathrm{CDH}$ rats in this study. This may be explained by the decreased $\mathrm{NO}$ availability, or by the process of eNOS uncoupling. In case of decreased bioavailability of the cofactor tetrahydrobiopterin (BH4),
eNOS produces superoxide instead of NO [31]. This superoxide leads to oxidative stress, which has been observed in vessels of patients with $\mathrm{PH}$ [32]. The enhanced activation of the ETA receptor, as mentioned before, might lead to the increase in superoxide production through the induction of reactive oxygen species (ROS) and can thereby induce SMC proliferation and vasoconstriction. Thus, eNOS uncoupling leads to a reduction in NO bioavailability without a necessary change in the amount of eNOS [31]. Furthermore, we 

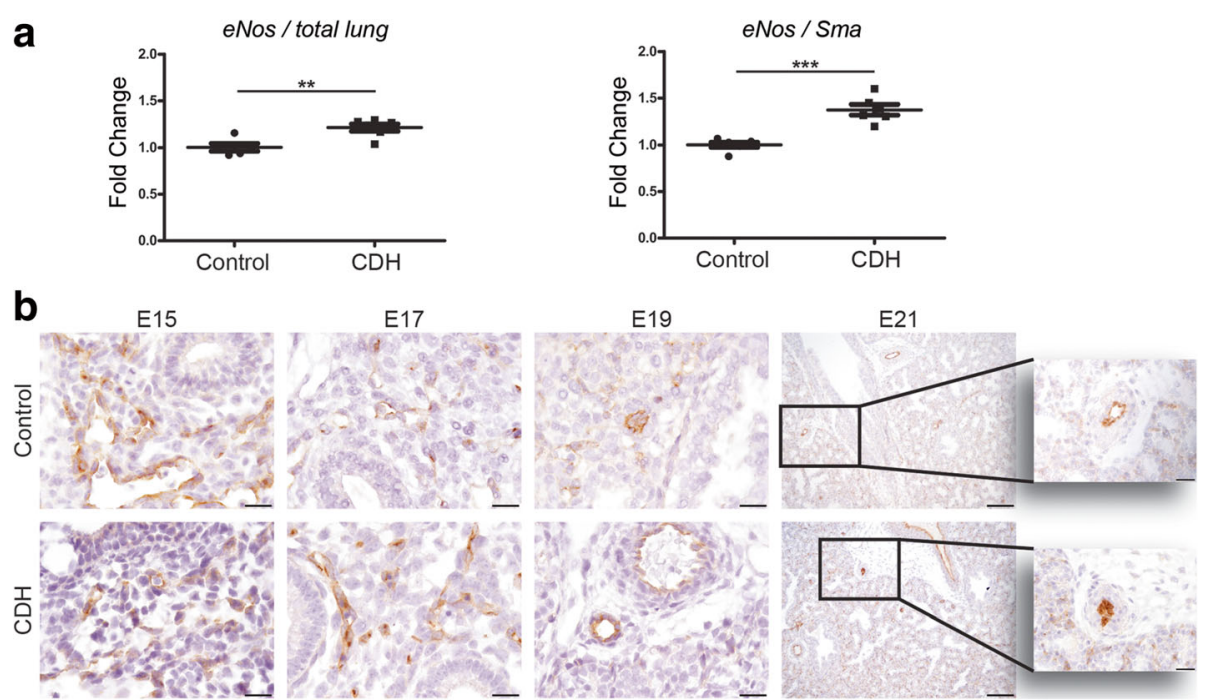

Fig. 6 Increased eNOS expression in lungs of CDH rats. a eNOS expression compared to total rat lungs (left) or to the pulmonary Sma ${ }^{+}$smooth muscle cells fraction (right) shows increased expression in CDH lungs. $\mathbf{b}$ Representative images show increased expression of eNOS in the vessels of the lungs of $\mathrm{CDH}$ rat pups at E21, but not at other stages of gestation. ${ }^{* *} p<0.01,{ }^{* * *} p<0.001$. Error bars represent SD. Arrows indicate vessels, A indicates airways. Scale bars represent $100 \mu \mathrm{m}$ (low power) and $20 \mu \mathrm{m}$ (high power) and $50 \mu \mathrm{m}$
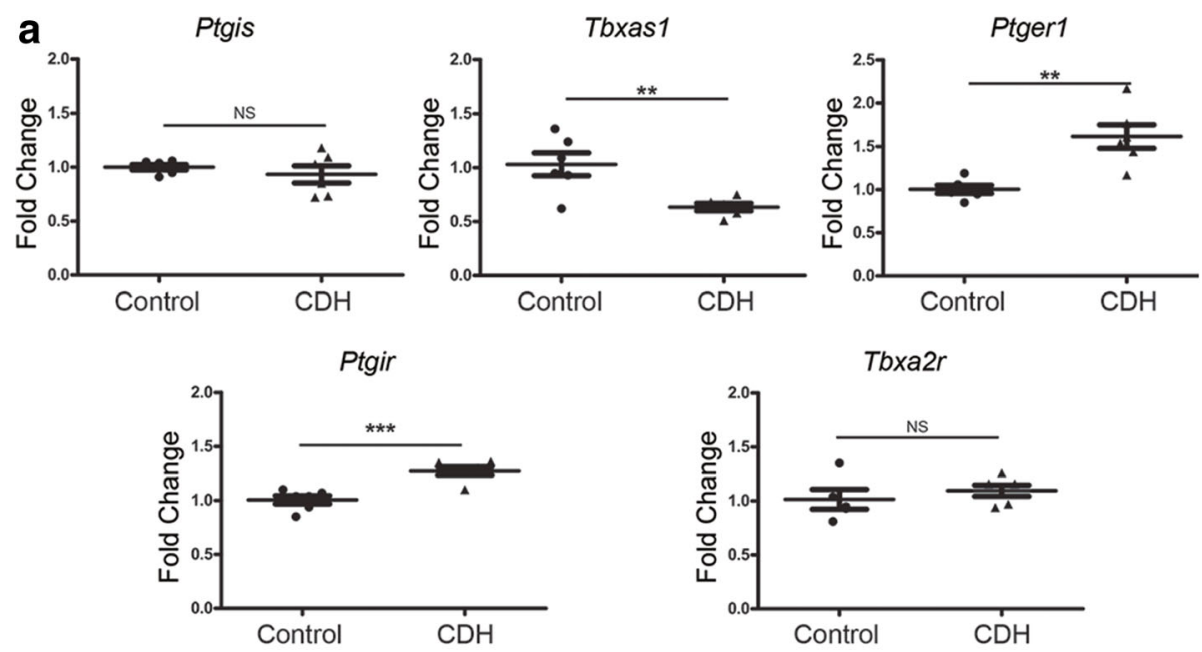

b
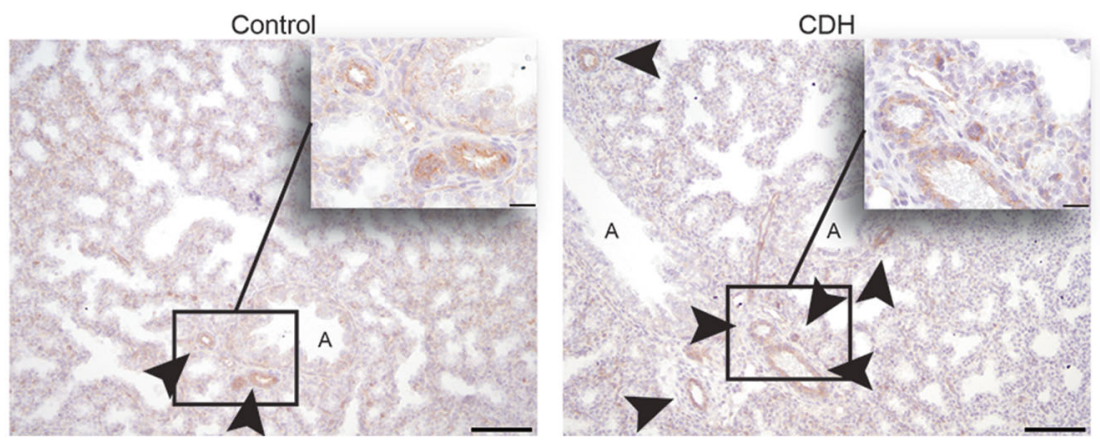

Fig. 7 Prostacyclin expression in rat pups. a Relative gene expression of prostaglandin I synthase (Ptgis), thromboxane synthase (Tbxas 1), prostaglandin-I $\mathrm{I}_{2}$ receptor (Ptgir) and prostaglandin-E1 receptor (Ptger1) in lungs of control and CDH rat pups. $\mathbf{b}$ Representative images showing the protein expression of PTGIR in the pulmonary vessels in control and CDH lungs. ${ }^{* *} p<0.01,{ }^{* * *} p<0.001$. Error bars represent SD. Arrows indicate vessels, A indicates airways. Scale bars represent $100 \mu \mathrm{m}$ (low power) and $20 \mu \mathrm{m}$ (high power) 
have shown a slight increase in expression of the cGMPspecific phosphodiesterase 5 (Pde5) in the NO pathway in nitrofen treated rat pups previously. However, no differences were found in its phosphorylation or its downstream targets, protein kinase G1 (Prkg1) and Prkg2 [27].

The increased expression of PTGIR in control lungs during gestation could result from the gradual increase of placental $\mathrm{PGI}_{2}$ toward term [33]. The decreased expression in $\mathrm{CDH}$ may be a sign of reduced activation of this pathway. In contrast to our human results, we found no differences in the expression of Ptgir in $\mathrm{CDH}$ rat pups and an increase of this receptor on mRNA level. Since $\mathrm{PGI}_{2}$ is a potent vasodilator and thromboxane A2 (TXA2) a potent vasoconstrictor, the increased expression of Ptgir and decreased expression of Tbxas1 was unexpected. However, this aberrant balance between $\mathrm{PGI}_{2}$ and TXA2 in $\mathrm{CDH}$ was already previously described by our group [34]. We showed an increased level of 6-keto-PGF ${ }_{1 \alpha}$, the stable metabolite of $\mathrm{PGI}_{2}$, and an increased ratio of 6-keto-PGF $1 \alpha$ and TXA2 in both lung homogenates and broncho-alveolar lavage (BAL) fluid of nitrofen treated rat pups. The discrepancy between the increased mRNA expression of Ptgir in $\mathrm{CDH}$ lungs and the absence of differences at the protein level is most likely caused by the difference in sensitivity between qPCRs and IHC. Furthermore, the different results in human and rat could be explained by the fact that we only used the most severe cases of human $\mathrm{CDH}$ where the rat model covers all cases.

Current treatment of $\mathrm{CDH}$ patients with $\mathrm{PH}$ is not evidence based [3] and most patients respond poorly to the used medication. Inhaled NO (iNO) is most commonly used as a first line drug, but its use varies significantly among different centers internationally [35]. In contrast to the promising results of iNO in patients with persistent pulmonary hypertension of the newborn [36], studies in $\mathrm{CDH}$ have failed to show its efficacy [35, 37], as no trials have been performed to evaluate the potential role of iNO specifically in $\mathrm{CDH}$ patients. Apart from iNO therapy there are some case reports on the use of sildenafil and prostacyclins in $\mathrm{CDH}$ patients with variable results $[25,26,38,39]$. However, administration of enteral sildenafil in neonates leads to highly variable plasma concentrations because of variable gut absorption and/or limited hepatic clearance [40]. The recent availability of intravenous sildenafil may change its application [41], but solid pharmacokinetic data on optimal dosage are still to be published. Treatment with endothelin receptor antagonists is even a bigger problem since these drugs are only available in oral form, while data of its use in newborns are virtually absent concerning dosage absorption and safety. The fact that the current therapy should be considered mainly as" trial and error" and is effective in the minority of patients with $\mathrm{CDH}$ strengthens our results that there are possibly more pathways affected. Furthermore, the severity of $\mathrm{PH}$ in $\mathrm{CDH}$ patients has been known as an important predictor of the outcome and further evaluation of current therapies has been recommended by experts in the field [5]. Future treatment should become more personalized in this group of patients using pathway directed clinical trials and risk stratification [42].

Although the nitrofen rat model is well established, there are still differences in embryonic maturation between rat and human, which may have affected the results. Furthermore, ideally, we would like to be able to directly correlate the findings of aberrant expression of the different vasoactive pathways with the individual response of patients to specific vasoactive drugs. However, given the overall limitations of these types of studies and the lack of material of patients who did respond to one of the three therapies, this remains impossible as repeated lung biopsies would be needed to accomplish this.

\section{Conclusions}

In conclusion, our study shows the aberrant expression of specific vasodilator drug targets and crucial, ratelimiting factors in human $\mathrm{CDH}$ and the nitrofen rat model in both the endothelin, $\mathrm{NO}$ and $\mathrm{PGI}_{2}$ pathway already early during development. Since $\mathrm{PH}$ is still a major problem and the most important cause of morbidity and mortality in $\mathrm{CDH}$ patients nowadays while current treatment strategies are disappointing, a good insight in these pathways is needed for specific and patient directed targeting of pharmacotherapy.

\section{Abbreviations}

CDH: Congenital diaphragmatic hernia; CGMP: Cyclic guanosine monophosphate; ECE-1: Endothelin converting enzyme 1; eNOS: Endothelial nitric oxide synthase; ET: Endothelin; ET-1: Endothelin 1; ETA: Endothelin receptor A; ETB: Endothelin receptor B; IHC: Immunohistochemistry; LH: Lung hypoplasia; NO: Nitric oxide; PDE5: Phosphodiesterase 5; PGl2: Prostacyclin; PH: Pulmonary hypertension; PRKG1: Protein kinase G1; PRKG2: Protein kinase G2; PTGER1: Prostaglandin-E receptor; PTGIR: Prostaglandin-I2 receptor; PTGIS: Prostaglandin- $I_{2}$ synthase; qPCR: Quantitative real-time polymerase chain reaction; TBXA2r: Thromboxane receptor; TBXAS1: Thromboxane synthase; TXA2: Thromboxane

\section{Acknowledgements}

Not applicable.

\section{Authors'contributions}

Concept and design of study, D.S.M., D.T. and R.J.R. Acquisition, analysis and interpretation of data, D.S.M., M.J.B., D.T. and R.J.R. Drafting of manuscript, D.S.M., D.T. and R.J.R. Review of manuscript for important intellectual content, D.S.M., R.M.H.W., D.T. and R.J.R. Final approval of manuscript, D.S.M., M.J.B., R.M.H.W., D.T. and R.J.R. Study supervision, D.T. and R.J.R. All authors read and approved the final manuscript.

\section{Funding}

This study was supported in part by the Sophia Foundation for Medical Research grant number 678 . 


\section{Availability of data and materials}

The datasets used and/or analysed during the current study are available from the corresponding author on reasonable request.

\section{Ethics approval and consent to participate}

Human lung samples were retrieved from the archives of the Department of Pathology of the Erasmus Medical Center, Rotterdam, following approval by the Erasmus MC Medical Ethical Committee. According to Dutch law following consent to perform autopsy, no separate consent is needed from parents to perform additional staining of tissues.

All animal experiments were approved by an independent animal ethical committee and according to national guidelines.

\section{Consent for publication}

Not applicable.

\section{Competing interests}

The authors declare that they have no competing interests.

\section{Publisher's Note}

Springer Nature remains neutral with regard to jurisdictional claims in published maps and institutional affiliations.

\section{Received: 5 July 2017 Accepted: 31 October 2017}

\section{Published online: 07 November 2017}

\section{References}

1. Lally KP. Congenital diaphragmatic hernia - the past 25 (or so) years. J Pediatr Surg. 2016;51:695-8.

2. Sluiter I, Reiss I, Kraemer U, Krijger R, Tibboel D, Rottier RJ. Vascular abnormalities in human newborns with pulmonary hypertension. Expert Rev Respir Med. 2011;5:245-56.

3. Puligandla PS, Grabowski J, Austin M, Hedrick H, Renaud E, Arnold M, Williams RF, Graziano K, Dasgupta R, McKee M, et al. Management of congenital diaphragmatic hernia: a systematic review from the APSA outcomes and evidence based practice committee. J Pediatr Surg. 2015;50: 1958-70.

4. Snoek KG, Reiss IK, Greenough A, Capolupo I, Urlesberger B, Wessel L, Storme L, Deprest J, Schaible T, van Heijst A, et al. Standardized Postnatal Management of Infants with Congenital Diaphragmatic Hernia in Europe: The CDH EURO Consortium Consensus - 2015 Update. Neonatology. 2016; 110:66-74.

5. Kotecha S, Barbato A, Bush A, Claus F, Davenport M, Delacourt C, Deprest J, Eber E, Frenckner B, Greenough A, et al. Congenital diaphragmatic hernia. Eur Respir J. 2012:39:820-9.

6. de Lagausie P, de Buys-Roessingh A, Ferkdadji L, Saada J, Aisenfisz S, Martinez-Vinson C, Fund X, Cayuela JM, Peuchmaur M, Mercier JC, Berrebi D. Endothelin receptor expression in human lungs of newborns with congenital diaphragmatic hernia. J Pathol. 2005;205:112-8.

7. Dingemann J, Doi T, Ruttenstock E, Puri P. Upregulation of endothelin receptors $\mathrm{a}$ and $\mathrm{B}$ in the nitrofen induced hypoplastic lung occurs early in gestation. Pediatr Surg Int. 2010;26:65-9.

8. Davenport AP, Hyndman KA, Dhaun N, Southan C, Kohan DE, Pollock JS, Pollock DM, Webb DJ, Maguire JJ. Endothelin. Pharmacol Rev. 2016; 68:357-418

9. Keller RL, Tacy TA, Hendricks-Munoz K, Xu J, Moon-Grady AJ, Neuhaus J, Moore P, Nobuhara KK, Hawgood S, Fineman JR. Congenital diaphragmatic hernia: endothelin-1, pulmonary hypertension, and disease severity. Am J Respir Crit Care Med. 2010;182:555-61.

10. Michael JR, Markewitz BA. Endothelins and the lung. Am J Respir Crit Care Med. 1996;154:555-81.

11. Fagan KA, Tyler RC, Sato K, Fouty BW, Morris KG Jr, Huang PL, McMurtry IF, Rodman DM. Relative contributions of endothelial, inducible, and neuronal NOS to tone in the murine pulmonary circulation. Am J Phys. 1999;277: L472-8.

12. Hoehn T, Stiller B, McPhaden AR, Wadsworth RM. Nitric oxide synthases in infants and children with pulmonary hypertension and congenital heart disease. Respir Res. 2009;10:110.

13. North AJ, Moya FR, Mysore MR, Thomas VL, Wells LB, Wu LC, Shaul PW. Pulmonary endothelial nitric oxide synthase gene expression is decreased in a rat model of congenital diaphragmatic hernia. Am J Respir Cell Mol Biol. 1995;13:676-82

14. Solari V, Piotrowska AP, Puri P. Expression of heme oxygenase-1 and endothelial nitric oxide synthase in the lung of newborns with congenital diaphragmatic hernia and persistent pulmonary hypertension. J Pediatr Surg. 2003;38:808-13.

15. Hofmann A, Gosemann JH, Takahashi T, Friedmacher F, Duess JW, Puri P. Imbalance of caveolin-1 and eNOS expression in the pulmonary vasculature of experimental diaphragmatic hernia. Birth Defects Res B Dev Reprod Toxicol. 2014;101:341-6.

16. de Rooij JD, Hosgor M, ljzendoorn Y, Rottier R, Groenman FA, Tibboel D, de Krijger RR. Expression of angiogenesis-related factors in lungs of patients with congenital diaphragmatic hernia and pulmonary hypoplasia of other causes. Pediatr Dev Pathol. 2004;7:468-77.

17. Sood BG, Wykes S, Landa M, De Jesus L, Rabah R. Expression of eNOS in the lungs of neonates with pulmonary hypertension. Exp Mol Pathol. 2011;90:9-12.

18. Shinkai T, Shima $H$, Solari V, Puri P. Expression of vasoactive mediators during mechanical ventilation in nitrofen-induced diaphragmatic hernia in rats. Pediatr Surg Int. 2005;21:143-7.

19. Shehata SM, Sharma HS, Mooi WJ, Tibboel D. Pulmonary hypertension in human newborns with congenital diaphragmatic hernia is associated with decreased vascular expression of nitric-oxide synthase. Cell Biochem Biophys. 2006:44:147-55.

20. Gao Y, Raj JU. Regulation of the pulmonary circulation in the fetus and newborn. Physiol Rev. 2010;90:1291-335.

21. De Jaegere AP, van den Anker JN. Endotracheal instillation of prostacyclin in preterm infants with persistent pulmonary hypertension. Eur Respir J. 1998; 12:932-4.

22. Kelly LK, Porta NF, Goodman DM, Carroll CL, Steinhorn RH. Inhaled prostacyclin for term infants with persistent pulmonary hypertension refractory to inhaled nitric oxide. J Pediatr. 2002;141:830-2.

23. Sood BG, Delaney-Black V, Aranda JV, Shankaran S. Aerosolized PGE1: a selective pulmonary vasodilator in neonatal hypoxemic respiratory failure results of a phase I/II open label clinical trial. Pediatr Res. 2004; 56:579-85.

24. De Luca D, Zecca E, Vento G, De Carolis MP, Romagnoli C. Transient effect of epoprostenol and sildenafil combined with iNO for pulmonary hypertension in congenital diaphragmatic hernia. Paediatr Anaesth. 2006;16: 597-8.

25. Olson E, Lusk LA, Fineman JR, Robertson L, Keller RL. Short-term Treprostinil use in infants with congenital diaphragmatic hernia following repair. J Pediatr. 2015;167:762-4.

26. Skarda DE, Yoder BA, Anstadt EE, Lally PA, Greene T, McFadden M, Rollins MD. Epoprostenol does not affect mortality in neonates with congenital diaphragmatic hernia. Eur J Pediatr Surg. 2015;25:454-9.

27. Mous DS, Kool HM, Buscop-van Kempen MJ, Koning AH, Dzyubachyk O, Wijnen RM, Tibboel D, Rottier RJ. Clinically relevant timing of antenatal sildenafil treatment reduces pulmonary vascular remodeling in congenital diaphragmatic hernia. Am J Physiol Lung Cell Mol Physiol. 2016:311:L734-42.

28. Rajatapiti P, van der Horst IW, de Rooij JD, Tran MG, Maxwell PH, Tibboel D, Rottier R, de Krijger RR. Expression of hypoxia-inducible factors in normal human lung development. Pediatr Dev Pathol. 2008;11:193-9.

29. Makanga M, Maruyama H, Dewachter C, Da Costa AM, Hupkens E, de Medina G, Naeije R, Dewachter L. Prevention of pulmonary hypoplasia and pulmonary vascular remodeling by antenatal simvastatin treatment in nitrofen-induced congenital diaphragmatic hernia. Am J Physiol Lung Cell Mol Physiol. 2015;308: L672-82.

30. Kuruppu S, Smith Al. Endothelin converting Enzyme-1 phosphorylation and trafficking. FEBS Lett. 2012;586:2212-7.

31. Roe ND, Ren J. Nitric oxide synthase uncoupling: a therapeutic target in cardiovascular diseases. Vasc Pharmacol. 2012;57:168-72.

32. Bowers R, Cool C, Murphy RC, Tuder RM, Hopken MW, Flores SC, Voelkel NF. Oxidative stress in severe pulmonary hypertension. Am J Respir Crit Care Med. 2004;169:764-9.

33. Walsh SW. Eicosanoids in preeclampsia. Prostaglandins Leukot Essent Fatty Acids. 2004;70:223-32

34. Ijsselstijn H, Zijlstra FJ, Van Dijk JP, De Jongste JC, Tibboel D. Lung eicosanoids in perinatal rats with congenital diaphragmatic hernia. Mediat Inflamm. 1997;6:39-45. 
35. Putnam LR, Tsao K, Morini F, Lally PA, Miller CC, Lally KP, Harting MT. Congenital diaphragmatic hernia study $\mathrm{G}$ : evaluation of variability in inhaled nitric oxide use and pulmonary hypertension in patients with congenital diaphragmatic hernia. JAMA Pediatr. 2016;170(12):1188-1194.

36. Roberts JD Jr, Fineman JR, Morin FC 3rd, Shaul PW, Rimar S, Schreiber MD, Polin RA, Zwass MS, Zayek MM, Gross I, et al. Inhaled nitric oxide and persistent pulmonary hypertension of the newborn. The inhaled nitric oxide study group. N Engl J Med. 1997;336:605-10.

37. Inhaled nitric oxide and hypoxic respiratory failure in infants with congenita diaphragmatic hernia. The Neonatal Inhaled Nitric Oxide Study Group (NINOS). Pediatrics. 1997;99:838-45.

38. Bialkowski A, Moenkemeyer F, Patel N. Intravenous sildenafil in the management of pulmonary hypertension associated with congenital diaphragmatic hernia. Eur J Pediatr Surg. 2015;25:171-6.

39. Noori S, Friedlich P, Wong P, Garingo A, Seri I. Cardiovascular effects of sildenafil in neonates and infants with congenital diaphragmatic hernia and pulmonary hypertension. Neonatology. 2007:91:92-100.

40. Ahsman MJ, Witjes BC, Wildschut ED, Sluiter I, Vulto AG, Tibboel D, Mathot RA. Sildenafil exposure in neonates with pulmonary hypertension after administration via a nasogastric tube. Arch Dis Child Fetal Neonatal Ed. 2010; 95:F109-14.

41. Steinhorn RH, Kinsella JP, Pierce C, Butrous G, Dilleen M, Oakes M, Wessel DL. Intravenous sildenafil in the treatment of neonates with persistent pulmonary hypertension. J Pediatr. 2009;155:841-7. e841

42. Akinkuotu AC, Cruz SM, Abbas PI, Lee TC, Welty SE, Olutoye OO, Cassady Cl, Mehollin-Ray AR, Ruano R, Belfort MA, Cass DL. Risk-stratification of severity for infants with $\mathrm{CDH}$ : prenatal versus postnatal predictors of outcome. J Pediatr Surg. 2016:51:44-8.

43. Kobayashi H, Puri P. Plasma endothelin levels in congenital diaphragmatic hernia. J Pediatr Surg. 1994;29:1258-61.

44. Coppola CP, Au-Fliegner M, Gosche JR. Endothelin-1 pulmonary vasoconstriction in rats with diaphragmatic hernia. J Surg Res. 1998;76:74-8.

\section{Submit your next manuscript to BioMed Central and we will help you at every step:}

- We accept pre-submission inquiries

- Our selector tool helps you to find the most relevant journal

- We provide round the clock customer support

- Convenient online submission

- Thorough peer review

- Inclusion in PubMed and all major indexing services

- Maximum visibility for your research

Submit your manuscript at www.biomedcentral.com/submit 